\title{
Correction to: Changes in the Participants in a Community-Based Positive Youth Development Program in Hong Kong: Objective Outcome Evaluation Using a One-Group Pretest-Posttest Design
}

\author{
Cecilia M. S. Ma ${ }^{1}$ - Daniel T. L. Shek ${ }^{1}$. \\ Jenna M. T. Chen ${ }^{1}$
}

Published online: 22 June 2018

(C) The Author(s) 2018

\section{Correction to: Applied Research Quality Life https://doi.org/10.1007/s11482-018-9632-1}

The article Changes in the Participants in a Community-Based Positive Youth Development Program in Hong Kong: Objective Outcome Evaluation Using a One-Group Pretest-Posttest Design, written by Cecilia M. S. Ma, Daniel T. L. Shek and Jenna M. T. Chen, was originally published electronically on the publisher's internet portal (currently SpringerLink) on 27 April 2018 without open access.

With the author(s)' decision to opt for Open Choice the copyright of the article changed on June 2018 to (C) The Author(s) 2018 and the article is forthwith distributed under the terms of the Creative Commons Attribution 4.0 International License (http://creativecommons.org/licenses/by/4.0/), which permits use, duplication, adaptation, distribution and reproduction in any medium or format, as long as you give appropriate credit to the original author(s) and the source, provide a link to the Creative Commons license and indicate if changes were made.

The online version of the original article can be found at https://doi.org/10.1007/s11482-018-9632-1

Cecilia M. S. Ma

cecilia.ma@polyu.edu.hk

1 Department of Applied Social Sciences, The Hong Kong Polytechnic University, HJ431, Hunghom, Kowloon, Hong Kong 
Open Access This article is distributed under the terms of the Creative Commons Attribution 4.0 International License (http://creativecommons.org/licenses/by/4.0/), which permits use, duplication, adaptation, distribution and reproduction in any medium or format, as long as you give appropriate credit to the original author(s) and the source, provide a link to the Creative Commons license and indicate if changes were made. 